\title{
РЕЧЕВЫЕ СТРАТЕГИИ И ТАКТИКИ В ПРЕДВЫБОРНЫХ ДЕБАТАХ ДЖОЗЕФА БАЙДЕНА
}

\section{SPEECH STRATEGIES AND TACTICS OF JOSEPH BIDEN'S PRE-ELECTION DEBATES \\ Ya. Demkina}

Summary: Joseph Biden's speech strategies and tactics are considered in numerous examples of his pre-election debates. The use of various speech tools to implement political actions in the presidential election process is investigated in this work. An analysis of the speech techniques used in U.S. political discourse to persuade citizens to cast their votes for a particular candidate, particularly Joseph Biden, is presented in this article.

Keywords: political discourse, speech strategies and tactics, linguistic method, discourse-analysis, nominalization, metaphor, lexical repetitions, semantic meaning, persuasive policy tactics.

\author{
Демкина Яна Юрьевна \\ Аспирант, Санкт-Петербургский государственный \\ электротехнический университет «ЛЭТИ» \\ им. В.И. Ульянова (Ленина), \\ yanademkina@mail.ru
}

Аннотация: Рассматриваются речевые стратегии и тактики Джозефа Байдена на многочисленных примерах из его предвыборных речей. Исследуется применение разнообразных речевых средств для реализации политических действий в процессе президентских выборов. Представлен анализ речевых приемов, используемых в политическом дискурсе (ША в целях убеждения граждан отдать свои голоса за конкретного кандидата, в частности, за Джозефа Байдена.

Ключевые слова: политический дискурс, речевые стратегии и тактики, лингвистический метод, дискурс-анализ, номинализация, метафора, лексические повторы, семантическое значение, персуазивные тактики политики.

образных речевых средств Джозефом Байденом для реализации политических действий в процессе президентских выборов. Анализ речевых стратегий и тактик, используемых в предвыборных речах Джозефа Байдена, был построен на основе дискурс-анализа. Исследование речевых приемов, употребляемых в политическом дискурсе 46-го президента США, было проведено с помощью лингвистического метода анализа устных и письменных текстов.

Для осуществления поставленной цели в статье необходимо вспомнить, что под понятием «стратегия» подразумевается достижение и решение трудной задачи. Коммуникативная стратегия включает в себя выбор ресурсов, представленных в виде стилистических средств, вербальных и невербальных ходов, целью которых является влияние на адресата через языковые тактики, обусловливающие внешнюю и внутреннюю структуру текста [3, с. 113]. Стратегии политического дискурса реализуются с помощью речевых тактик, которые характеризуются определенным набором приемов и языковых средств.

Под «тактикой» понимается искусство ведения боя и совокупность методов и приемов, применяемых для достижения намеченной цели. Коммуникативную тактику можно представлять как обоснование речевых действий, определяемых задачей в рамках речевой стратегии [2, с. 7].

Рассмотрим следующие стратегии политического дискурса: стратегия на понижение; стратегия на повы- 
шение; стратегия театральности, стратегия присвоения ярлыков, реализуемые через речевые тактики, представляющие собой совокупность лингвистических приемов, которые способны манипулировать сознанием и мнением избирателей [3, с. 168].

Стратегия на понижение имеет цель изобразить политического противника в отрицательном свете, применяя следующие тактики: тактика анализ - «минус», тактика обвинения, тактика безличного обвинения, тактика обличения, тактика оскорбления, тактика угрозы.

\section{Результаты и обсужление}

На основе дискурс-анализа обнаружена в политическом дискурсе предвыборных дебатов, выступлений Джозефа Байдена стратегия на понижение. Применяя лингвистический метод, можно утверждать, что для реализации стратегии на понижение вновь избранный президент США использовал на лексическом уровне слова с негативной семантической и коннотативной окраской, отрицательно характеризующие поступки его оппонента. В результате метода сплошной выборки рассмотрим пример:

And so, the point was, he missed enormous opportunities and kept saying things that weren't true [4].

И так, дело было в том, что он упустил огромные возможности и продолжал говорить вещи, которые не были правдой [4].

Джозеф Байден для осуществления стратегии на понижение применил тактику анализ - «минус», использующую лексические средства, а именно, словосочетание missed enormous opportunities, явно намекающее на ошибку Дональда Трампа и дискредитирующее его в глазах электората. Вновь избранный президент США использовал глагол missed с негативной коннотацией, с негативным оценочным значением, выражающий вину 45ого президента США в условиях пандемии. Наблюдается и тактика обвинения в данном фрагменте речи, которая осуществлена с помощью лексических средств, описывающих ситуацию в негативном свете. Джозеф Байден прямо обвинил Дональда Трампа в упущенной возможности исправить ситуацию в стране, вызванную распространением коронавирусной инфекции, в результате которой погибли 220 тысяч американцев. Обвиняя Дональда Трампа в неуспешности выполнения обязанностей президента, Байден прибег к тактике оскорбления, с помощью которой эмоционально воздействовал на электорат. Для осуществления этой тактики используется метафора enormous opportunities (на стилистическом уровне).

Пронаблюдаем следующий пример, где Джозеф Байден употребил тактику критики оппонента:
Number one, President Trump talks about things that just aren't accurate about everything from vaccines; we're going to have one right away, it's going to happen and so on [4].

Президент Трамп неверно говорит о том, что касается вакцины. Он говорит, что мы ее очень скоро получим, что это вот-вот произойдет. Но речь не о нем [4].

Джозеф Байден критиковал деятельность Дональда Трампа, связанную с борьбой против коронавируса. При исследовании данного образца политической речи выявлены отрицательные формы aren't accurate about everything from vaccines, которые выражают номинализацию неправильности действий Дональда Трампа.

Прямое обвинение, выдвинутое Джозефом Байденом в адрес Дональда Трампа, определило речевую стратегию на понижение агрессии, реализуемую посредством тактики прямого обвинения.

46-й президент США применил тактику прямого обвинения в бездействии Дональда Трампа в области здравоохранения, осуществив стратегию речевой агрессии:

He has not done healthcare [4].

Он ничего не сделал для здравоохранения [4].

Джозеф Байден ввел отрицательную форму глагола has not done для номинализации неуспешной деятельности бывшего президента США, реализуя стратегию речевой агрессии. Критикуя действия Дональда Трампа в области экономики в стране в период распространения COVID-19, Джозеф Байден употребил фразовый глагол shut down:

We didn't shut down the economy. This is his economy he shut down [4].

Мы не остановили экономику. Это его экономика, которую он закрыл [4].

Семантическое значение данного фразового глагола shut down означает прекращение работы, подчеркивая, что неправильные решения Дональда Трампа привели к бедствию населения и снижению уровня жизни в США.

Приведем очередной пример применения Джозефом Байденом тактики прямого обвинения:

Russia pays you ... China pays you ... Publish your tax returns or stop talking about corruption [4]!

Россия тебе платит... Китай тебе платит... Опубликуй свои налоговые декларации или перестань говорить о коррупции [4]!

В результате исследования стратегии на понижение, использованной Байденом, было установлено, что вновь избранный президент США не применял по отношению к Дональду Трампу тактику безличного обвинения, тактику обличения, тактику оскорбления, тактику угрозы. 
Вновь избранный президент США прибегал к стратегии на повышение, которая дает возможность представить себя в положительном свете перед электоратом, осуществляя эту стратегию через тактику анализ-«плюс», тактику презентации [3, с. 176].

Представим пример применения Джозефом Байденом тактики презентации, которая позволила ему предстать заботливым и искренним лидером своей страны пред избирателями:

My whole soul was in it today. On this January day, I am fully focused on uniting America, uniting our people, uniting our nation. And I ask every American to support me in this matter. Unite to fight enemies: anger, resentment, hatred, extremism, lawlessness, violence, disease, unemployment and hopelessness [5].

Вся моя душа была в ней сегодня. В этот январский день я полностью сосредоточен на том, чтобы объединить Америку, объединить наш народ, объединить нашу нацию. И я прошу каждого американиа поддержать меня в этом деле. Объединиться для борьбы с врагами: гневом, обидой, ненавистью, экстремизмом, беззаконием, насилием, болезнями, безработицей и безнадежностью [5].

Джозеф Байден использовал лексические единицы с положительной коннотацией Му whole soul was in it today, представляющие 46-ого президента США как руководителя страны, думающего об американцах.

46-й президент США прибег к тактике анализ - «плюс»: we do that, тактике презентации: I guarantee уои. Джозеф Байден имплицитно предлагает с помощью этих тактик верить избирателям ему, как новому лидеру страны, как президенту США.

And we must step towards this moment as the United States of America. If we do that, I guarantee you that we will not fail. We have never, ever, ever failed in America when we acted together [5].

И мы должны шагнуть навстречу этому моменту, будучи Соединенными Штатами Америки. Если мы сделаем это, я гарантирую вам, что мы не потерпим неудачу [5].

В ходе исследования политической речи было выявлено, что Джозеф Байден не использовал тактику отвода критики, не оправдывался перед электоратом.

В политическом дискурсе инаугурационной речи Джозефа Байдена наблюдаем стратегию театральности, имеющую цель эмоционального воздействия на избирателя:

America must be better than it is now. And I believe that America is better [5].

Америка должна быть лучше, чем сейчас. И я верю в то, что Америка будет лучше [5].

Анализируя этот фрагмент политического дискурса Джозефа Байдена на основе дискурс-анализа, мы установили, что 46-й президент США использовал тактику обещания, с помощью которой дал понять избирателям, что им следует верить его обязательствам: I believe that America is better. Джозеф Байден подчеркнул, что он вместе с американцами сделает Америку лучше.

Пример тактики обещания, применимой Джозефом Байденом в своей инаугурационной речи:

I promise you l'll be president for all Americans. All Americans [5].

Я вам обещаю, что буду президентом для всех американцев. Всех американцев [5].

46-й президент США употребил лексические и синтаксические повторы в данных примерах: better - повторены два раза, for all Americans. All Americans - два повтора использованы в примере. Джозеф Байден осуществил тактику обещания через форму будущего времени глагола совершенного вида promise, который оказывает влияние на избирателей с целью убеждения в правдивости слов кандидата.

Тактика побуждения представлена в политическом дискурсе Джозефа Байдена следующим образом:

hear me: dissent should not lead to separation. I promise you l'll be president for all Americans. All Americans.

услышьте меня: несогласие не должно вести к разъединению. Я вам обещаю, что буду президентом для всех американцев. Всех американцев.

В результате настоящих исследований выяснилось, что предложение dissent should not lead to separation применяется в тактике побуждения в речи Джозефа Байдена с целью доказательства, что вновь избранный президент един с американским народом. Тактику побуждения подчеркивает прагматическую и тематическую структуру текста [1, с. 15-16].

\section{Bыво $\Delta$}

Подводя общий итог, отметим, что и в политическом дискурсе предвыборных дебатов Джозеф Байден не использовал тактику размежевания для реализации стратегии театральности, поскольку ясно дал понять всем американцам, что его единство с народом нерушимо. Вновь избранный президент США наиболее часто использовал в предвыборных дебатах стратегию на понижение, применяя тактику обвинения политического оппонента, употребляя лексику в прямом ее значении, подчеркивая негативные моменты политики Дональда Трампа и подозревая его в коррупции. Джо Байден преимущественно применял тактику обещания, убеждая 
американский электорат, что выполнит свои предвыборные обязательства.

В результате проведенных исследований мы считаем возможным заявить, что стратегическое и тактическое планирование речевых действий было выполнено 46-м президентом США ярко и эмоционально. Гипотеза, выдвинутая в статье, доказана, все перечисленные речевые стратегии и тактики Джозефа Байдена являются персуазивными, направленными на убеж- дение электората в искренности действий кандидата, в необходимости его избрания, и показывают потенциальному избирателю, что Джозеф Байден не скомпрометирован перед американским обществом. Вероятно, во время президентства речевые стратегии и тактики Джозефа Байдена претерпят некоторое изменение, но, если он пойдет на второй срок, мы ожидаем их повторного использования (разумеется, с учетом будущих реалий США и, тем более, ожидаемого отсутствия такого соперника, как Дональд Трамп).

\section{ЛИТЕРАТУРА}

1. Голоднов А.В. Лингвопрагматические особенности персуазивной коммуникации (на примере современой немецкоязычной рекламы): Автореф. дис... канд. филол. наук: 10.02.04 / А.В. Голоднов: - СПб: СПбГУ, 2003. - 23 с.

2. Кубрякова Е.С. 0 типах дискурсивной деятельности. — Вестник МГлУ. — 2003. Выпуск 478. С. 5-10.

3. Михалева 0.Л. Политический дискурс. Специфика манипулятивного воздействия. М.: Либроком, 2009, 256 с.

4. Donald Trump \& Joe Biden 1st Presidential Debate Transcript 2020. URL: [Электронный ресурс]. - Режим доступа: https://www.rev.com/blog/transcripts/donaldtrump-joe-biden-1st-presidential-debate-transcript-2020. - Дата обращения: 20.03.2021

5. United States of Department. URL: [Электронный ресурс]. - Режим доступа: https://www.state.gov. - Дата обращения: 23.03.2021

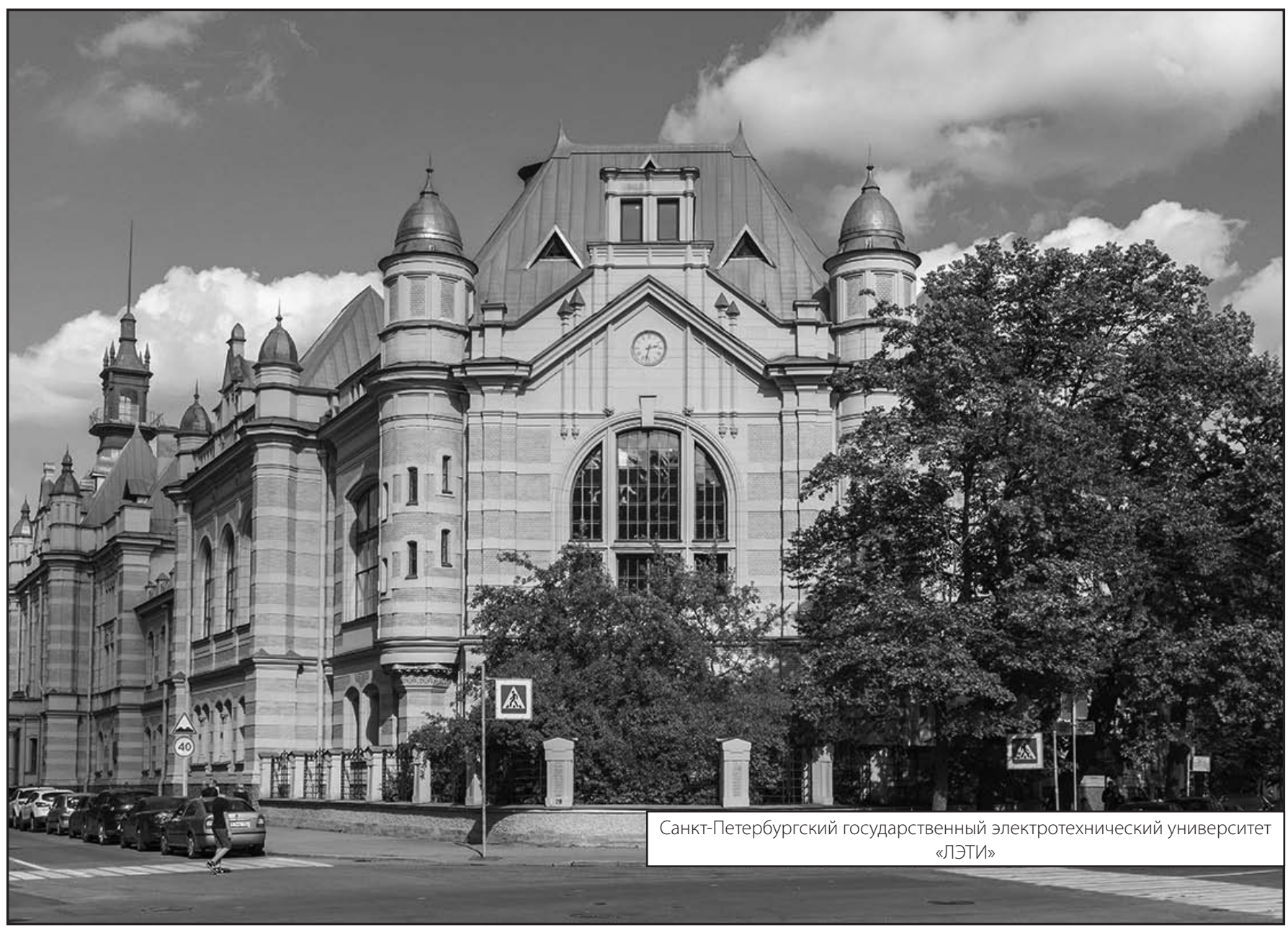

